\title{
The Zirconia Ceramic: Strengths and Weaknesses
}

\author{
Elie E. Daou ${ }^{*}$
}

Department of Prosthodontics, Lebanese University, Beirut, Lebanon

\begin{abstract}
Metal ceramic restorations were considered the gold standard as reliable materials. Increasing demand for esthetics supported the commercialization of new metal free restorations. A growing demand is rising for zirconia prostheses. Peer-reviewed articles published till July 2013 were identified through a Medline (Pubmed and Elsevier). Emphasizing was made on zirconia properties and applications. Zirconia materials are able to withstand posterior physiologic loads. Although zirconia cores are considered as reliable materials, these restorations are not problem free.
\end{abstract}

Keywords: Esthetics, mechanical properties, zirconia restorations.

\section{INTRODUCTION}

When restoring a tooth, the clinician faces the dilemma: Which material should he use? [1]. The major factors that may influence the final choice are esthetics and strength of the prostheses.

Metal ceramic fixed partial dentures (FPDs) are considered the gold standard, as reliable materials. However, the request for esthetic dentistry as well as the rising question regarding biocompatibility of dental alloys, support the commercialization of new products [2]. Nowadays, allceramic prostheses are replacing, more and more, metalbased restorations [3]. A variety of ceramic systems are developed for single crowns or fixed dental prostheses (FDPs) with an excellent esthetic outcome [4].

Traditional ceramics (glass- glass-reinforced, and feldspathic ceramics) and also $\mathrm{Al}_{2} \mathrm{O}_{3}$-reinforced ceramics encountered some problems, especially in the molar region [4]. Ceramic material used, core-veneered bond-strength, and crown thickness are some factors essential to withstand occlusal forces [5]. The reliability of industrially prefabricated ceramics block appears to be more consistent than laboratory manually processed ceramics $[6,7]$.

Transformation-toughened zirconia is prone to be a successful alternative in the different clinical situations compared to other all-ceramic systems [8]. Their mechanical and optical properties allowed them to be used as a framework material. In vitro studies demonstrated a flexural strength of 900-1200MPa [9, 10], and a fracture toughness of 9-10MPam1/2 [2, 11]. The restorations are processed either by soft machining of presintered blanks followed by sintering at high temperature, or by hard machining of fully sintered blanks $[12,13]$.

*Address correspondence to this author at the Department of Prosthodontics, Lebanese University, Beirut, Lebanon; Tel: +9613625049;

Fax: +9619440445; E-mail: dreliedaou@yahoo.com
This review article describes the current status of zirconia-based fixed restorations, including results of current in vitro studies and the clinical performance of these restorations [14].

Since its development in 2001 [12], direct ceramic softmachining of pre-sintered $3 \mathrm{Y}-\mathrm{TZP}$ is now on the market. First, the die or the wax pattern is scanned, the computer software (CAD) designs an enlarged restoration and computer aided machining mill a pre-sintered ceramic blank. The restoration is then sintered at high temperature [13].

Hard-machining Y-TZP blanks consist of milling restorations in very high density blocks, presintered at $99 \%$ of the theoretical density [13]. The milling system has to be particularly robust due to the high hardness and low machinability of fully sintered Y-TZP [13].

Same 5-years survival rates have been reported for all-ceramic crowns and metal-ceramic for anterior teeth. When utilized for premolars and molars the success decreased to $90.4 \%$ and $84.4 \%$ respectively for InCeram crowns and glass-ceramic crowns [15-17]. The force, contact area and duration were greater for molar chewing cycles than incisor ones [18]. The most common complication encountered with all-ceramic crowns was crown fracture [19].

Up to 3-years published controlled clinical studies of zirconia-based crowns reported lower complication rates $[20,21]$. The authors concluded that Y-TZP could sufficiently withstand functional load in the posterior zone [22]. However, as mentioned by Conrad and others, following traditional preparation guidelines will better distribute stress during dynamic loading of the restoration [5, 23].

An electronic search has been conducted, during July 2013, via PubMed and Elsevier. Peer-reviewed articles were targeted. The following key-words have been used: Zirconia, zirconia restorations, allceram, zirconia crowns, zirconia FPDs, zirconia bonding, and zirconia strength. Available full-text articles were read. Related articles were also scrutinized. No hand search was driven. 


\section{FRACTURE RESISTANCE}

The mechanical properties of zirconia allowed them to be used in posterior FPDs and permit substantial reduction in core thickness [13].

Under ambient pressure, the temperature will influence the crystallographic form of unalloyed zirconia. At room temperature and upon heating up to $1170{ }^{\circ} \mathrm{C}$, the structure is monoclinic. Then it is tetragonal between 1170 and $2370{ }^{\circ} \mathrm{C}$ and cubic above $2370{ }^{\circ} \mathrm{C}$ and up to the melting point [24]. Upon cooling, transformation from the tetragonal $(t)$ phase to the monoclinic $(m)$ phase will induce a substantial increase in volume $(\sim 4.5 \%)$. This will lead to catastrophic failure. Adding $\mathrm{CaO}, \mathrm{MgO}, \mathrm{Y}_{2} \mathrm{O}_{3}$ or $\mathrm{CeO}_{2}$ to zirconia-alloys allows the retention of the tetragonal structure at room temperature. This will control the stress-inducing $t \rightarrow m$ transformation. Compressive stresses developed in the vicinity of a crack tip, arrest crack propagation and lead to high toughness [13, 25, 26].

Composition, grain size, shape of the zirconia particles, type and amount of the stabilizing oxides, interaction of zirconia with other phases and processing are also factors that have impact on the metastability of the transformation [26].

However, grinding or sandblasting are responsible to cause the $t \rightarrow m$ transformation altering the phase integrity of the material and increasing the susceptibility to aging $[27,28]$. The presence of water will exacerbate this welldocumented "Low Temperature Degradation" (LTD) $[29,30]$. The $\mathrm{Y}_{2} \mathrm{O}_{3}$ can react with the aqueous environment producing yttrium hydroxide $\left(\mathrm{Y}[\mathrm{OH}]_{3} \mathrm{H}_{2} \mathrm{O}\right)$ [31, 27]. Grain pullout and microcracking as well as decrease in strength are reported consequences of this aging process [13, 32]. Frameworks or parts of a framework that are not veneered as well as zirconia implants and abutments exposed to the oral environment, are subjected to this phenomenon. This is why during framework design, non-veneered zirconia should be avoided [27].

Innovative bioceramics such as zirconia magnesia $(\mathrm{Mg}-$ PSZ with bioactive glass coating) [33] and alumina composites TZP stabilized [34] are recently reported as degradationfree materials [35].

Both in vitro and in vivo studies demonstrated that fracture of the connectors was the exclusive mode of failure in all-ceramic FPDs [36, 37]. Connector fracture was initiated at the gingival embrasure. Concentration of tensile stresses can be reduced by larger radius of curvature at the gingival embrasure [38]. Whereas, sharp occlusal embrasures did not affect FPDs' fracture resistance [39, 40].

An occlusogingival height of $2.5 \mathrm{~mm}$ and a buccolingual width of $2.5 \mathrm{~mm}$ of the connectors (a connector surface area of $6.25 \mathrm{~mm}^{2}$ ) are sufficient to ensure long-term success of metal-ceramic FPDs [41]. These dimensions are achievable both in the anterior and in the posterior segments.

Mechanical strength of zirconia frameworks is up to three-times higher than other allceram. It can withstand physiological occlusal forces applied in the posterior region [4, 14, 42, 43] Even rare, framework fractures in all-ceram FPDs were reported in the connector region [44-46, 4].
Therefore, connector dimensions are crucial for fracture resistance [40].

Fracture propagated from the gingival surface of the connector toward the pontic [47]. A connector dimension of $3 \times 3 \mathrm{~mm}$ increased the fracture strength of zirconia-based FPDs by $20 \%$ [44, 48, 49]. Required dimensions for the connector could still be smaller than for other all-ceramic core materials [40]. Even though, some authors recommended a connector dimension of $4 \times 4 \mathrm{~mm}$ and that the framework must support the veneering porcelain, which should not include more than $2.0 \mathrm{~mm}$ of unsupported veneering material $[14,27,50-52]$. Worth noting that bulk fracture appears to be quite uncommon [13].

The major problem encountered is porcelain cracking. The difficulties are material-specific with an incidence from 8 to $50 \%[53,54]$. Thickness ratios or framework design also play a role. For comparison, porcelain problems on metalceramic prosthesis over a 10 years observation period was reported to be, no higher than $6 \%$ for most alternative alloys, [55]. $98 \%$ completely intact porcelain at 5 years was reported for goldbased alloy [56, 69]. Thus, porcelain-zirconia compatibility is to be considered [13].

Zirconia-porcelain interface may be involved in crazing and chipping during function. Stresses could be related to surface property, as bulk thermal expansion/contraction mismatches does not appear to be the cause [13]. The aggressivity of silicate glasses as solvents of refractory materials at high temperature is known [57]. Under firing conditions, aluminum oxide is soluble in dental porcelains [58]. Cerium and zirconium diffuse into a glass used to infiltrate a partially sintered Ce-TZP powder [59]. Lessening of stabilizing dopants (e.g., Y and Ce) might induce local changes in zirconia surface [60] resulting in destabilization of the $t$ phase [61] with quite high local associated strains [62]. Liquid silicate can penetrate the grain boundaries perhaps analogous to water penetration of Y-TZP [13, 63].

\section{CHIPPING AND FAILURES}

Chipping is defined as "a typical failure of contact loadings, normally produced when a crack generated or propagated by contact loads deflects due to the presence of a free surface nearby" $[64,65]$. Tensile stress induces fracture of the brittle ceramic usually perpendicular to the applied force [66].

Thermal coefficient mismatches, processing (porosity, impurity inclusion) and inherent material defects (large grains, residual scratches) will increase the probability of crack propagation under loading [67]. Brittle fracture of ceramics will be triggered adjacent to these zones [66].

In the case of metal-ceramic prostheses, an adherent layer of oxide is essential to achieve a strong bond. This will enhance the wettability and the adherence of the ceramic. When the temperature attains a certain level, part of this oxide will be dissolved into the glass. In the case of nickelchromium alloys, excess oxide production will cause weak bonding [68]. High-gold alloys will produce an adequate oxide layer for a solid bond with the porcelain [68]. 
The zirconia core-veneer bond should also be strong enough to gain profit from exceptional properties of the framework. However, according to Aboushelib, this bond strength is lower than for other all-ceram systems [69]. This can induce chipping and delamination under friction. Framework surface treatment, the surface finish, the type and method of application of the veneer ceramic will affect this bonding [70].

If no fractures of the zirconia framework have been reported [2], chip-off fracture rates up to $20 \%$ was observed at 5 -years follow-up period $[4,5]$. In the case of metal framework FPDs, a review of the literature revealed either no fracture of the veneering ceramic [71] or substantially lower fracture rates ranging from $2.7 \%$ up to $5.5 \%$ for observation periods from 10 to 15 years $[2,72,73]$.

Adequate framework design, proper veneering ceramic support and thickness are factors implicated in the ceramic survival [74]. Moreover, occlusal forces, such as direction, magnitude and frequency are to be taken into consideration $[2,75]$. Roughness of the veneer that results from occlusal contacts or grinding may induct chipping. Fractography analysis revealed that crack propagation originated from wear area and occlusal adjustments [27, 76, 77]. Studies have shown that sandblasting and sharp indentations even at very low loads are very harmful to long-term longevity of zirconia [78-80].

Marchack et al. demonstrated that scanning of full contour waxing will provide an optimal porcelain thickness on appropriate coping design [81]. This will decrease porcelain fracture $[14,82]$. It has been recommended that the veneer thickness does not exceed two-fold of the core thickness. The pontic framework must have an anatomical shape to support veneers' cusps [83]. However, a completely suitable veneer system has not yet been found. Differences in microtensile bond strength between several veneering porcelains have been shown [84]. Strong veneering systems are recommended to avoid chipping [4].

For others, the thermal expansion coefficient (TEC) plays a major role far before the zirconia-veneer bond strength [85, 86, 77]. Most manufacturers provide veneering porcelains having a slight mismatch between their porcelain and zirconia, with the porcelain having approximately TEC lower than the zirconia TEC [84]. Desirable residual compressive stress in the veneering ceramic is present when a framework material with a slightly higher TEC is used [87]. In contrast, when Zirconia's TEC is lower than ceramic's, veneer delamination and microcracks occurred $[69,88]$. This approach is used for most metal-ceramic systems and non-zirconia all-ceramic systems. [89, 90, 13] Therefore, if a compatibility issue is occurring with Y-TZP, it is likely not only due to a simple thermal expansion coefficient mismatch between the bulk materials [13]. Low fusing veneering ceramics with similar TEC have been developed. Grain size may also play a role [2]. The wide range of sintering temperature has an incidence on the particle size and later on the phase stability of zirconia-yittria [13].

Some recent studies described a layering method of indirect composite onto a zirconia framework [61-66]. A short term in-vitro study reported a superior bond strength by us- ing a priming agent containing the functional monomer MDP [61]. Plastic and viscoelastic effects, as well as susceptibility to creep And recovery $[67,68]$ are advantageous properties of using composite, especially in areas of high occlusal stress $[69,87]$.

Zirconia presents a thermoconductivity much lower than that of other framework materials $[6,9]$. This low thermal conductivity retards the ceramic cooling rate at the interface. This generates thermal residual stress $[91,92]$. It may induce thermal cycling delamination of the veneering porcelain [2]. The effect of different cooling rates (rapid and slow) on the bond strength between layering porcelain and zirconia ceramics has been assessed [93, 94]. Prolonged cooling phases have been proposed to reduce this stress and veneer chipping $[83,95,96]$. Slow cooling time ameliorated the resistance of the veneered zirconia restorations $[76,97]$, and enhanced the shear bond strength [93]. However, Gostemeyer et al. argued that adding 5 min cooling in the furnace lowered the bond strength [94]. Komine noticed that these conflicting findings are the result of different cooling and testing methods [87].

Applying a liner material has been proposed to mask the opacity of the zirconia-core. Unfortunately, this reduced the core-veneer bond-strength and increased the percentage of interfacial failure [70, 84]. Kim and Fischer agreed on the negative effect of liner application [86, 98, 99]. Aboushelid contraindicated their use with Press-on ceramics [84]. The lower strength of liners compared to dentine ceramic may play a role in these negative results. Still, others found that liner materials enhances the bond strength between zirconia and some layering ceramic [87].

\section{LAYERED /PRESSED VENEERING CERAMICS}

Cohesive and adhesive failures of the veneering are recurrent complications of veneered zirconia frameworks [76].

To counteract this tendency, the "overpressing technique" has been proposed. A specific ceramic is pressed onto the zirconia framework [100]. According to Beuer et al. [101] this technique is reliable since no chipping has been detected [14].

Fabrication of conventional dental porcelains consists of a frit condensation followed by a sintering process. Sintering may introduce thermally induced residual stresses [102]. This can modify the measured biaxial flexure strength [103105]. The moisture content of the veneering material during sintering might induce changes in the zirconia/veneering interface and provoke transformation from the tetragonal phase to the monoclinic phase [106]. Swain et al. [95] preconized that residual stresses and contact-induced cracking will develop chip-fracture. Beuer et al. [100] reported higher strength of CAD/CAM veneering ceramic compared to the layered veneering technique. Using of the pressed ceramic may reduce the chipping incidence [4], since the heatpressing fabrication method would reduce the formation of large flaws and minimize the thermally induces residual stresses $[102,105]$. The manufactured blanks are reported flawless. Greater porosities are entrapped during fabrication stages in dental laboratory, added to human errors [107, 108]. The shrinkage level of the porcelain may be related to the ratio of the mixed powder/liquid veneering ceramic. Minimal three 
firing cycles are needed. Catastrophic failures can be induced by the incorporation of small impurities like inhomogenities, pores, since cracks cannot be healed but slow growth may occur under oral conditions [108, 109]. The pressing technique permit the creation of desired tooth anatomy while minimizing firing shrinkage [110].

The manufactured CAD/CAM veneer will be joined to the zirconia framework by fusion glass ceramic or by using resin cement [111]. Lithium disilicate has been proposed to be connected to zirconia framework by glass fusion ceramic $[76,112]$. Higher tensile strength of press-on veneers and the superior quality of the interface can prevent porcelain chipping [84]. These materials exhibited better fracture strength and fatigue behavior when compared to the hand-layered ceramics. The latter show early veneer failures under mouthmotion cyclic loading [76, 113].

In one recent study, overpressed zirconia three-unit posterior prostheses had significantly less fractures and chippings compared with layered ones [114]. In another study no chipping was observed [101, 108]. Ishibe and Aboushelid recommended the application of press-on veneer ceramics directly onto air-borne-particle-abraded surfaces [70, 84, $115,116]$. However, other studies found no difference in fracture incidence between the pressed and layered techniques [100, 108, 117].

Connector design had an incidence on milled ceramic fracture resistance, but not the pressed ceramic [118].

\section{SHEAR BOND STRENGTH AND INFLUENCE OF ARTIFICIAL AGEING}

In metal-ceramic prostheses, as determined by the International Standards Organization (ISO) [119], the minimum required bond strength between metal and layering porcelain is $25 \mathrm{MPa}$. No such estimate has been yet determined for all-ceram [87]. Comparison between zirconia- and metalceramic restorations found a similar bond strength $[88,115$, $120,121]$. Other studies reported greater bond strength between porcelain and zirconia than for metal-zirconia [2, 122]. Results are conflicting [87].

Guess found metal-ceramic shear bond strength (SBS) higher than zirconia-ceramic one's. Thermocycling has no effect on zirconia-ceramic bond [2]. Yet, Silva noticed that in contrast to Y-TZP systems where failures were accelerated by fatigue, metal-ceramic restorations failures occurred as a function of load and not fatigue [123].

The difference in the results between metal- and zirconiaceramic SBS could be reported to the dissimilar adhesion mechanisms. If mechanical interlocking and chemical bond resulting from suitable metal oxidation and interdiffusion of ions are essential in the metal ceramic interface, the Y-TZPceramic bonding mechanisms are still unclear [124, 125]. For the latter, some micromechanical interactions can just be assumed based on the wettability of zirconia-core by veneering ceramic [2].

When Ishibe and Aboushelib compared zirconia-layered ceramic shear bond strength to zirconia-pressed one, they found equivalent results [70, 84, 115].
Oral fluids are known to facilitate stress corrosion of ceramic materials. Water molecule will diffuse into the glass and provoke a corrosion mechanism [126]. Dissolution of ceramic can happen through 2 ways: by ionic exchange during exposure to an acidic solution, or by breakdown of Si-O network in a basic solution [127]. The intensity of chemical deterioration is related to the glass matrix composition and the ratio of crystal incorporation [66]. This will result in slow crack growth and may lead to failure of ceramic restorations in the oral cavity complex situation [2, 128, 129]. So some concerns are assessed regarding zirconium dioxide structural stability when it's exposed to oral environment $[6,27]$.

Different zirconia systems were tested in vitro, using artificial aging, through dynamic loading and thermal cycling. No significant effects on the fracture load were observed for 3-unit FDPs, and no failures occurred [4, 130, 131]. Thermocycling had no incidence on the zirconia-layered-ceramic bond $[2,88]$. The bond strength stability is equivalent to results found about bonding of porcelain-metal framework $[87,88,132]$.

Schmitter noticed that artificial aging has no incidence on CAD/CAM ceramics, in contrast with the manually veneered crowns [76]. Another study found no difference between the two veneering methods after aging [108]. No difference in the fatigue properties of the Zirconia Everest ${ }^{\circledR}$ core material following sintering or heat pressing of the veneering material was detected [133].

Analyses of the fracture surfaces for the pressed ceramic, revealed a combined adhesive and cohesive failure scheme independent of the ageing [76]. Even on polished zirconia, the failure was mostly cohesive within the veneering ceramic $[69,86]$. The flexure strength varied between 70 and $100 \mathrm{MPa}$, depending of the product $[134,108]$. The flexural strength of the zirconia veneering porcelain, similar to metal-ceramics, will block the propagation of the crack due to the tetragonal phase $[69,108]$.

Stawarczyk concluded that overpressed veneering porcelains for zirconia single crown frameworks exhibited similar or better fracture load compared with layered ones [108]. Guess noticed that hand-layer-veneered zirconia crowns revealed a high susceptibility to mouth-motion cyclic loading in early veneer failures [113]. Other factors such as grain size and shape and porosity should also be considered [26]. Grain size strongly affect the mechanical properties of 3 Y-TZP [14, 20, 21]. On the other hand, sintering temperatures will influence the grain size and the phase stability of 3Y-TZP [13].

Soft machining restorations are sintered at a later stage. This will prevent the stress-induced transformation from tetragonal to monoclinic. The final surface will virtually be free of monoclinic phase unless grinding adjustments are needed or sandblasting is performed [13]. In contrast, hardmachined restorations of fully sintered $3 \mathrm{Y}$-TZP blocks contain a significant amount of monoclinic zirconia [26]. This may result in surface microcracking, higher susceptibility to LTD and lower reliability [27].

Several searches studied the fatigue behavior of 3Y-TZP [28, 29-31]. When tested in cyclic loading, both sandblasting 
and sharp indentations even at very low loads are harmful to the long-term performance of 3Y-TZP [13, 29-31]. The presence of residual stresses was detrimental in promoting LTD [13].

Worth to be noticed that the pressable ceramic materials showed significantly less change in marginal opening than metal ceramic and copy milled ceramic crowns [16].

\section{COLOR AND ESTHETICS}

Tooth Enamel, constituted of $97 \%$ hydroxyapatite mineral, is very translucent and can transmit up to $70 \%$ of light. Dentin is also able to transmit up to $30 \%$ of light. The esthetic dilemma for metal-ceramic restorations is that opaque porcelain is needed to mask a metal substrate. It will reflect light and decrease translucency. Consequently, they will often appear brighter intraorally [5, 135]. In-Ceram Spinnell had higher levels of translucency than In-Ceram Alumina (VITA Zahnfabrik), followed by In-Ceram Zirconia (VITA Zahnfabrik), which was comparable to a metal alloy [5].

Zirconia framework is esthetically better accepted than metallic framework, but it remains clinically too white and opaque. Therefore, manufacturers introduce colored zirconia framework to ameliorate the overall matching color [136]. Different techniques have been proposed: adding pigments to the initial zirconia ceramic powder, dipping zirconia milled frameworks in dissolved coloring agents, applying liner material to sintered framework $[69,137]$. Thinner veneer is then required to mask the underlying framework [138].

The ability to control the shade of the core may also eliminate the need to veneer the lingual and gingival aspects of the connectors in those situations where the interocclusaldistance is limited and the required connector dimensions are minimally achieved. In addition, the palatal aspect of anterior crowns and FPDs may be fabricated of the core material exclusively in situations of extensive vertical overlap and lack of space for lingual veneering porcelain [40, 139].

Individualized colored overpressed ceramics have been also proposed as a quick and easy technique [108]. Excellent esthetic and perfect matching are difficult to attain, as appearance will rely on precolored ingots. To enhance esthetic, a layering ceramic can also be applied over an pressed-on veneer [140].

Lava system (3M ESPE Dental Products), which is relatively translucent but may still mask colored abutment, is proposed in 7 shades, permitting shading from the intaglio surface to the outer [139].

The increase of the concentration of the coloring pigments at grain boundaries could be at the expense of the stabilizing elements. This may result in higher percentage of tetragonal-monoclinic transformation. If this transformation occurs on the surface of the framework, this will provoke grain pullout and surface lifts [70]. This phenomenon results from competitive displacement of the stabilizing elements by the metallic pigments in the liquid state. The latter have a melting point lower than the yetrium oxide one [70]. A minor alteration of the location or the concentration of the stabilizing elements can alter the mechanical properties of the zirconia framework [141]. A fatigue process started on individual surface areas will lead to monoclinic spots and results in surface microcracking and lifts. The color pigments at grain boundaries replacing the reduction of yttrium will affect the slowly extend of this process toward the bulk of the material [142, 143].

One study showed that the bond strength of colored zirconia is significantly lower compared to non-colored zirconia [70]. When the framework is colored by dipping in pigment solution, the pigments will concentrate on the outer surface. Those surface pigments tend to crystallize on the surface and weaken the bond with the veneer ceramic [70].

\section{DISCUSSION}

Variable study conditions and plethora of materials available made the comparison of the results from relevant literature, a challenging issue [5]. Usually, a failure in any clinical trial results from a combination of causes or events [1]. Worth noting, there is a remarkable emphasis on clinical examination of the zirconia product [13], even though some of these studies lack scientific support [144]. Reproducing intra-oral conditions, during the in vitro studies, is quite difficult. An effort was made to create artificial oral environments by applying cyclic forces in artificial saliva, under fluctuating temperature [145]. Long-term clinical studies are still needed to make conclusions [5]. In the era of evidencebased dentistry, reinforcing standardization of clinical cohort studies will permit more efficient conclusions [4]. It has been noted that some granted research centers may be reluctant to publish bad results [146].

Concerns regarding metal-ceramic restorations biocompatibility limitations and optical qualities provoked the shift to all-ceramic restorations placement. While achieving marginal accuracies equal to that of metal-ceramic crowns, Allceramic crowns provide superior gingival response [147].

Glass ceramic crowns, even those with a densely sintered alumina core, showed brittle fracture in the posterior region [148]. Patient selection may be critical and the technique remains sensitive [149]. Poor oral hygiene, high caries incidence, moderate gingival inflammation and severe parafunction are some of the exclusion criteria cited [150]. A coping design allowing optimal ceramic layering thickness, a uniform cement film, and an adequate TEC matching between the laminate and the core may reduce the stresses [148].

Studies reported that zirconia ceramic flexure strength and fracture toughness are twice that of alumina ceramics [151]. The partially stabilized tetragonal modification of zirconia to a monoclinic phase, induce by a tensile stress, exhibits $4 \%$ volume expansion. To propagate, the crack must overcome the compressive stresses generated at the crack tip [152, 153].

The aim of this review was not to evaluate survival and failure of different restorations. Authors agreed that Y-TZP can withstand physiologic functional loading forces and are comparable to metal-ceramic FPDs [27, 154]. Strength and marginal fit of zirconia ceramic has been confirmed by extensive laboratory testing $[155,156]$. Still 5 to 10 year clinical studies are needed to determine primary mode of failure and success rate [157]. 
The major complication reported is chipping of the veneer with a rate that will increase from $6 \%$ to $10 \%$ between 3 and 5 years, whereas these values are reported on a 10 years observation period for metal-ceramic restorations [27, 55]. Fracture of the zirconia framework is not probable [27]. Long-term success is essentially dependant of the performance of the veneering [74]. Minor chip-off of the layering ceramic has been reported as the most frequent complication [2]. Short-span posterior frameworks are reliable, whereas data is lacking for long span and cantilevers [4].

If bond failure has been pointed as chipping reason [158], differences in thermal coefficients [159], liner material and poor core wetting [84], veneer firing shrinkage [85, 86], phase transformation [160], loading stresses, flaw formation [161], coloring pigments [70] and surface properties [33] have been reported as potential causes. Upon fracture, similar to porcelain-alloys [162], a thin porcelain layer remained attached to the zirconia surface, showing that cohesive strength was lower than adhesive bond strength [27]. Even scientific evidence was lacking, Fischer assumed that bond between zirconia and ceramic was chemical [86]. Others go for mechanical interlocking added to cooling compressive stresses [163]. The ability of zirconia to counteract crack propagation will result in a crack deflection [164]. Framework design must provide uniform veneer support $[14,165$, 166]. Pressable materials with an increase of the crystalline content generally improved the mechanical properties [26].

Ceramic crowns made only of zirconia, monolithic zirconia crowns, are not used widely in clinical practice because of the absence of a sound standard and the possibility of wear of the opposing teeth due to the hardness of zirconia [65].

Even if zirconia frameworks are preferred in posterior situations, compared to other allceram materials [5], some limitations still exist and proper diagnosis is critical for success [167].

The quantity, size, and chemical properties of the crystals within the ceramic matrix will determine the opacity of a ceramic material [168]. In-ceram Zirconia (VITA Zahnfabrik, Bad Sackingen, Germany) is reported the least translucent when compared to other ceramics $[169,170]$.

While success rate for $35 \%$ partially stabilized zirconia has been evaluated promising [171], long-term clinical data remain rare [172]. The mechanical [173], esthetic [174], biocompatible [175], and metal-like radiopaque [176] properties allow the zirconia ceramics to be versatile, even though the opaque core limits their use in the anterior sextant [170]. Careful patient selection and operating technique are essential. Bruxers, periodontally involved teeth exhibiting increased mobility, and cantilever prostheses are to be avoided [172]. Fracture, located in the area between the retainer and pontic is the primary mode of failure. Under high tensile stress, it emanates from the gingival surface of the connectors, leading to catastrophic loss [177].

A framework design allowing for a uniform thickness and support of veneering porcelain has been shown to optimize the strength of bilayered specimens [178]. Radial surface cracks can be generated by Intaglio wall adjustments of the framework, either with a 50 micron or coarser diamond rotary cutting instrument, and under dry or water cooling. This will compromise the strength of the zirconia core [179]. Marginal fit has been reported similar to that of metalceramic restorations [180]. Cementation of zirconia-based FPDs with either composite resin, glass ionomer, or resinmodified glass ionomer cements have been proposed, even long-term data are lacking [157, 174, 181].

\section{CONCLUSION}

Zirconia restorative material is well-placed to satisfy esthetic requirements and to fulfill functional requirements. Further studies should be conducted to resolve the complications that may reduce restorations longevity.

Within its limitations, this review has pointed some of the strengths and weaknesses of this promising material.

1. Zirconia is able to withstand physiological posterior forces.

2. Zirconia-veneer bonding is not yet well understood.

3. Studies to reduce veneer chipping should be conducted.

4. Ageing process, coloring pigments and liner materials have negative impact on the veneer- zirconia bond strength.

5. Pressed veneer porcelain exhibit reduced fracture incidence compared to layered veneer.

6. New compatible high strength ceramic veneers would reduce chip-off incidence.

7. Framework design must provide anatomical support to the layer veneering ceramic.

Understanding each of these mechanisms will enhance the reliability of the zirconia as a multipurpose material.

\section{CONFLICT OF INTEREST}

The authors confirm that this article content has no conflicts of interest.

\section{ACKNOWLEDGEMENTS}

None declared.

\section{REFERENCES}

[1] Bayne SC. Dental restorations for oral rehabilitation - testing of laboratory properties versus clinical performance for clinical decision making. Review Article. J Oral Rehab 2007; 34: 921-32.

[2] Guess C, Kulis A, Witkowskia S, Wolkewitz M, ZhangY, Strub JR. Shear bond strengths between different zirconia cores and veneering ceramics and their susceptibility to thermocycling. Dent Mater 2008; 24: 1556-67.

[3] Heintze SD, Cavalleri A, Zellwegera G, Buchler A, Zappinia G. Fracture frequency of all-ceramic crowns during dynamic loading in a chewing simulator using different loading and luting protocols. Dent Mater 2008; 24: 1352-61.

[4] Schley JS, Heussen N, Reich S, Fischer J, Haselhuhn K, Wolfart S. Survival probability of zirconia-based fixed dental prostheses up to 5 yr: a systematic review of the literature. Eur J Oral Sci 2010; 118 : 443-50. 
[5] Conrad HJ, Seong WJ, Pesun IJ. Current ceramic materials and systems with clinical recommendations: A systematic review. J Prosthetic Dent 2007; 98: 389-404.

[6] Morrmann WH, Stawarczyk B, Ender A, Sener B, Attin T, Mehl A. Wear characteristics of current aesthetic dental restorative CAD/CAM materials: Two-body wear, gloss retention, roughness and Martens hardness. J Mechanic Behav Biomed Mater 2013; 20: 113-25.

[7] Wittneben JG, Robert FW, Weber HP, Gallucci GO. A Systematic Review of the Clinical Performance of CAD/CAM Single-Tooth Restorations. Int J Prosthodont 2009; 22: 466-71.

[8] Della Bona A, Robert Kelly J. The clinical success of all-ceramic restorations. JADA 2008; 139(suppl 4): 8-13.

[9] Tinschert J, Zwez D, Marx R, Anusavice KJ. Structural reliability of alumina-, feldspar-, leucite-, mica- and zirconia-based ceramics. J Dent 2000; 28: 529-35.

[10] Filser F, Kocher P, Weibel F. Reliability and strength of allceramic dental restorations fabricated by direct ceramic machining (DCM). Int J Comput Dent 2004; 89-106.

[11] Christel P, Meunier A, Heller M, Torre JP, Peille CN. Mechanical properties and short-term in vivo evaluation of yttrium-oxidepartially-stabilized zirconia. J Biomed Mater Res 1989; 23: 45-61.

[12] Filser F, Kocher P, Gauckler LJ. Net-shaping of ceramic components by direct ceramic machining. Assembly Autom 2003; 23: 382-90.

[13] Denry I, Kelly JR. State of the art of zirconia for dental applications. Dent Mater 2008; 24: 299-307.

[14] Komine F, Blatz MB, Matsumura H. Current status of Zircobiabased fixed restorations. J Oral Sci 2010; 52(4): 531-9.

[15] Pjetursson Bjarni E, Sailer I, Zwahlen M, Hammerle CHF. A systematic review of the survival and complication rates of all-ceramic and metal-ceramic reconstructions after an observation period of at least 3 years. Part I: single crowns. Clin Oral Impl Res 2007; 18(Suppl. 3): 73-85.

[16] Cho SH, Nagy WW, Goodman JT, Solomon E, Koike M. The effect of multiple firings on the marginal integrity of pressable ceramic single crowns. J Prosthetic Dent 2012; 107: 17-23.

[17] Galindo ML, Pedram P, Marinello CP. Estimating long-term survival of densely sintered alumina crowns: A cohort study over 10 years. J Prosthetic Dent 2011; 106: 23-8.

[18] Kohayama K, Hatakeyama E, Sasaki E, Azuma T, Karita K. Effect of sample thickness on bite force studied with a multiple-point sheet sensor. J Oral Rehab 2004; 31: 327-34.

[19] Goodacre CJ, Bernal G, Rungcharassaeng K, Kan JYK. Clinical complications in fixed prosthodontics. J Prosthetic Dent 2003; 90: $31-41$.

[20] Cehreli MC, Kokat A, Akca K. CAD/CAM Zirconia vs. slipcast glass-infiltrated Alumina/Zirconia all-ceramic crowns: 2-year results of a randomized controlled clinical trial. J App Oral Sci 2009; 17: 49-55.

[21] Encke BS, Heydecke G, Wolkewitz M, Strub JR. Results of a prospective randomized controlled trial of posterior $\mathrm{ZrSiO}(4)$ - ceramic crowns. J Oral Rehab 2009; 36: 226-35.

[22] Ortorp A, Maria KL, Carlsson GE. A 3-year retrospective and clinical follow-up study of zirconia single crowns performed in a private practice. J Dent 2009; 37: 731-6.

[23] Scurria MS, Badder JD, Shugars DA. Meta-analysis of fixed partial denture survival: prostheses and abutments. J Prosthetic Dent 1998; 79: 459-64.

[24] Kisi E, Howard C. Crystal structures of zirconia phases and their interrelation. Key Eng Mater 1998; 153/154: 1-35.

[25] Heuer AH, Lange FF, Swain MV, Evans AG. Transformation toughening: an overview. J Am Ceram Soc 1986; 69: i-iv.

[26] Guazzato M, Albakry M, Ringer S, Swain M. Strength, fracture toughness and microstructure of a selection of all-ceramic materials. part II. Zirconia-based dental ceramics. Dent Mater 2004; 20: 449-56.

[27] Koutayas SO, Vagkopoulos T, Pelekanos S, Koidis P, Strub JR. Zirconia in Dentistry: part 2. evidence-based clinical breakthrough. Eur J Esthet Dent 2009; 4: 348-80.

[28] Deville S, Chevalier J, Gremillard L. Influence of surface finish and residual stresses on the ageing sensitivity of biomedical grade zirconia. Biomaterials 2006; 27: 2186-92.

[29] Chevalier J, Cales B, Drouin JM. Low-temperature aging of Y-TZP ceramics. J Am Ceram Soc 1999; 82: 2150-4.
[30] Guo X. On the degradation of zirconia ceramics during lowtemperature annealing in water or water vapor. J Phys Chem Solids 1999; 60: 539-46.

[31] Lin JD, Duh JG, Lo CL. Mechanical properties and resistance to hydrothermal aging of ceria- and yttriadoped tetragonal zirconia ceramics. Mater Chem Phys 2002; 87: 808-18.

[32] Papanagiotou HP, Morgano S, Giordano RA, Pober R. In vitro evaluation of low-temperature aging effects and finishing procedures on the flexural strength and structural stability of Y-TZP dental ceramics. J Prosthetic Dent 2006; 96: 154-64.

[33] Rahaman MN, Li Y, Bal BS, Huang W. Functionally graded bioactive glass coating on magnesia partially stabilized zirconia for enhanced biocompatibility. J Mater Sci Mater Med (Mg-PSZ) 2008; 19: 2325-33.

[34] Kim DJ, Myung-Hyun L, Lee DY, Han JS. Mechanical properties, phase stability, and biocompatibility of $(\mathrm{Y}, \mathrm{Nb})-\mathrm{TZP} / \mathrm{Al}(2) \mathrm{O}(3)$ composite abutments for dental implant. J Biomed Mater Res 2000; 53: 438-43.

[35] Heness G, Ben-Nissan B. Innovative bioceramics. Mater Forum 2004; 27: 104-14.

[36] Suarez MJ, Lozano JF, Paz Salido M, Martinez F. Three-year clinical evaluation of In-Ceram Zirconia posterior FPDs. Int J Prosthodont 2004; 17: 35-8.

[37] Esquivel-Upshaw JF, Anusavice K, Young H, Jones J, Gibbs C. Clinical performance of lithia disilicate-based core ceramic for three-unit posterior FPDs. Int J Prosthodont 2004; 17: 469-75.

[38] Oh WS, Anusavice K. Effect of connector design on the fracture resistance of all-ceramic fixed partial dentures. J Prosthetic Dent 2002; 87: 536-42.

[39] Oh WS, Anusavice KJ. Effect of connector design on the fracture resistance of all-ceramic fixed partial dentures. J Prosthetic Dent 2002; 87: 536-42.

[40] Raigrodski AJ. Contemporary materials and technologies for allceramic fixed partial dentures: A review of the literature. J Prosthetic Dent 2004; 92: 557-62.

[41] Miller LL. Framework design in ceramo-metal restorations. Dent Clin North Am 1977; 21: 699-716.

[42] Att W, Grigoriadou M, Strub JR. $\mathrm{ZrO}_{2}$ three-unit fixed partial dentures: comparison of failure load before and after exposure to a mastication simulator. J Oral Rehabil 2007; 34: 282-90.

[43] Tinschert J, Gerd N, Mautsch W, Augthun M, Spiekermann H. Fracture resistance of lithium-disilicate-, alumina-, and zirconiabased three-unit fixed partial dentures. Int J Prosthodont 2001; 14: 231-8.

[44] Sundh A, Sjogren G. Fracture resistance of all-ceramic zirconia bridges with differing phase stabilizers and quality of sintering. Dent Mater 2006; 22: 778-84.

[45] Ttinschert J, Natt G, Mautsch W, Augthun M, Spiekermann H. Fracture resistance of lithium disilicate-, alumina-, and zirconiabased three-unit fixed partial dentures: a laboratory study. Int J Prosthodont 2001; 14: 231-8.

[46] Ttinschert J, Natt G, Mohrbotter N, Spiekermann H, Schulze KA Lifetime of alumina- and zirconia ceramics used for crown and bridge restorations. J Biomed Mater Res B Appl Biomater 2007; 80: $317-21$.

[47] Plengsombut K, Brewer JD, Monaco EA Jr., Davis EL. Effect of two connector designs on the fracture resistance of all-ceramic core materials for fixed dental prostheses. J Prosthetic Dent 2009; 101: 166-73.

[48] Bahat Z, Mahmoood DJ, Vult von Steyern P. Fracture strength of three-unit fixed partial denture cores (Y-TZP) with different connector dimension and design. Swed Dent J 2009; 33:149-59.

[49] Vult von Steyrn P. All-ceramic fixed partial dentures. Studies on aluminum oxide- and zirconium dioxide-based ceramic systems. Swed Dent J 2005; (Suppl): 1-69.

[50] Tsumita M, Kokubo Y, Vult von Steyern P, Fukushima S. Effect of framework shape on the fracture strength of implant-supported allceramic fixed partial dentures in the molar region. J Prosthodont 2008; 17: 274-85.

[51] Vult von Steyrn P, Carlsson P, Nilner K. All-ceramic fixed partial dentures designed according to the DC-Zirkon technique. A 2-year clinical study. J Oral Rehabil 2005; 32: 180-7.

[52] Larsson C, Holm L, Lovgern N, Kokubo Y, Vult von Steyern. Fracture strength of four-unit Y-TZP core designed with varying connector diameter: an in-vitro study. J Oral Rehabil 2007; 34 702-9. 
[53] von Steyern PV. All-ceramic fixed partial dentures. Studies on aluminum oxide- and zirconium dioxide-based ceramic systems. Swed Dent J Suppl 2005; 173: 1-69.

[54] Larsson C, Volt von Steyern P, Sunzel B, Nilner K. All-ceramic two- and five-unit implant-supported reconstructions. A randomized, prospective clinical trial. Swed Dent J 2006; 30: 45-53.

[55] Anderson RJ, Janes GR, Sabella LR, Morris HF. Comparison of the performance on prosthodontic criteria of several alternative alloys used for fixed crown and partial denture restorations: Department of Veterans Affairs Cooperative Studies project 147. J Prosthetic Dent 1993; 69: 1-8.

[56] Walter M, Reppel P, Boning K, Freesmeyer WB. Six year followup of titanium and high-gold porcelain-fused-to-metal fixed partial dentures. J Oral Rehabil 1999; 26: 91-6.

[57] Sandhage KH, Yurek GJ. Direct and indirect dissolution of sapphire in calcia-magnesia-alumina-silica melts: dissolution kinetics. J Am Ceram Soc 1990; 73: 3633-42.

[58] Kelly JR. Clinical fracture behavior and colloidal processing of glass-matrix dental ceramics: In Cambridge, MA: 1989, Harvard University .

[59] Durschang B, Raether F. Development of a glass-infiltrated ceramic for dental applications, Fraunhofer ISC Annual Report, 2002. http://www.isc.fraunhofer.de/german/improfil/presse/publikationen /media/e60-61.pdf.

[60] Kim DJ. Effect of $\mathrm{Ta}_{2} \mathrm{O}_{5}, \mathrm{Nb}_{2} \mathrm{O}_{5}$, and $\mathrm{HfO}_{2}$ alloying on the transformability of $\mathrm{Y}_{2} \mathrm{O}_{3}$-stabilized tetragonal $\mathrm{ZrO}_{2}$. J Am Ceram Soc 1990; 73: 115-20.

[61] Schubert H. Anisotropic thermal expansion coefficients of $\mathrm{Y}_{2} \mathrm{O}_{3^{-}}$ stabilized tetragonal zirconia. J Am Ceram Soc 1986; 69: 270-1.

[62] Matsui K, Horikoshi H, Ohmichi N, Ohgai M, Yoshida H, Ikuara Y. Cubic-formation and grain-growth mechanisms in tetragonal zirconia polycrystal. J Am Ceram Soc 2003; 86: 401-8.

[63] Kobayashi K, Kuwajima H, Masaki T. Phase change and mechanical properties of $\mathrm{ZrO}_{2}-\mathrm{Y}_{2} \mathrm{O}_{3}$ solid electrolyte after aging. Solid State Ionics 1981; 3(4): 489-95.

[64] Kou W, Molin M, SjoGren G. Surface roughness of five different dental ceramic core materials after grinding and polishing. J Oral Rehab 2006; 33: 117-24.

[65] Kim MJ, Oh SH, Kim JH, et al. Wear evaluation of the human enamel opposing different Y-TZP dental ceramics and other porcelains. J Dent 2012; 40: 979-88.

[66] Oh WS, Delong R, Anusavice KJ. Factors affecting enamel and ceramic wear: a literature review. J Prosthetic Dent 2002; 87: 4519.

[67] Denry I. How and when does fabrication damage adversely affect the clinical performance of ceramic restorations? Dent Mater 2013; 29: 85-96.

[68] McLean JW. Evolution of dental ceramics in the twentieth century. J Prosthetic Dent 2001; 85: 61-6.

[69] Aboushelib MN, de Jager N, Kleverlaan CJ, et al. Microtensile bond strength of different components of core veneered all-ceramic restorations. Dent Mater 2005; 21: 984-91.

[70] Aboushelib MN, Kleverlaan CJ, Feilzer AJ. Effect of zirconia type on its bond strength with different veneer ceramics. J Prosthodont 2008; 17: 401-8.

[71] Walter M, Reppel PD, Boning K, Freesmeyer WB. Six-year follow-up of titanium and high-gold porcelain-fused-to-metal fixed partial dentures. J Oral Rehab 1999; 26: 91-6.

[72] Coornaert J, Adriaens P, De Boever J. Long-term clinical study of porcelain-fused-to-gold restorations. J Prosthetic Dent 1984; 51: 338-42.

[73] Valderhaug J. A 15-year clinical evaluation of fixed prosthodontics. Acta Odontol Scand 1991; 49: 35-40.

[74] Sailer I, Feher A, Filser F. Prospective clinical study of zirconia posterior fixed partial dentures: 3-year follow up. Quint Int 2006; 37: 685-93.

[75] Raigrodski AJ, Gerard JC, Potiket N. The efficacy of posterior three-unit zirconium-oxide-based ceramic fixed partial dental prostheses: a prospective clinical pilot study. J Prosthetic Dent 2006; 96: 237-44.

[76] Schmitter M, Mueller D, Rues S. Chipping behaviour of allceramic crowns with zirconia framework and CAD/CAM manufactured veneer. J Dent 2012; 40: 154-62.

[77] Sailer I, Gottnerb J, Kanel S, Hämmerle CH. Randomized controlled clinical trial of zirconia-ceramic and metal-ceramic poste- rior fixed dental prostheses: a 3-year follow-up. Int J Prosthodont 2009; 22: 553-60.

[78] Zhang Y, Lawn BR. Fatigue sensitivity of Y-TZP to microscale sharp-contact flaws. J Biomed Mater Res: Appl Biomater 2005; 72B: 388-92.

[79] Zhang Y, Pajares A, Lawn BR. Fatigue and damage tolerance of YY-TZP ceramics in layered biomechanical systems. J Biomed YMater Res B Appl Biomater 2004; 71B: 166-71.

[80] Zhang Y, Lawn BR, Rekow ED, Thompson VP. Effect of sandblasting on the long-term performance of dental ceramics. J Biomed Mater Res B: Appl Biomater 2004; 71B: 381-6.

[81] Marchack BW, Futatsuki Y, Marchack CB, White SN. Customization of milled zirconia coping for all-ceramic crowns: a clinical report. J Prosthetic Dent 2008; 99: 169-73.

[82] Segal BS. Retrospective assessment of 546 all-ceramic anterior and posterior crowns in a general practice. J Prosthetic Dent 2001; 85: 544-50.

[83] Mitov G, Heintze SD, Walz S, Woll K, Muecklichd F, Pospiecha P. Wear behavior of dental Y-TZP ceramic against natural enamel after different finishing procedures. Dent Mater 2012; 28: 909-18.

[84] Aboushelib MN, Kleverlaan CJ, Feilzer AJ. Microtensile bond strength of different components of core veneered all-ceramic restorations. Part II: zirconia veneering ceramics. Dent Mater 2006; 22: 857-63.

[85] Fischer J, Stawarczyk B, Tomic M, Strub JR, Hammerle CHF. Effects of thermal misfit between different veneering ceramics and zirconia frameworks on in vitro fracture load of single crowns. Dent Mater 2007; 26(6): 766-72.

[86] Fischer J, Grohmann P, Stawarczyk B. Effect of zirconia surface treatments on the shear strength of zirconia/veneering ceramic composites. Dent Mater J 2008; 27: 448-54.

[87] Komine F, Strub JR, Matsumura H. Bonding between layering materials and zirconia frameworks. Jap Dental Sci Rev 2012; 48: 153-61.

[88] Saito A, Komine F, Blatz MB, Matsumura H. A comparison of bond strength of layered veneering porcelains to zirconia and metal. J Prosthetic Dent 2010; 104: 247-57.

[89] Shell JS, Nielsen JP. Study of the bond between gold alloys and porcelain. J Dent Res 1962; 41: 1424-37.

[90] Knap FJ, Ryge G. Study of bond strength of dental porcelain fused to metal. J Dent Res 1966; 45: 1047-51.

[91] Hermann I, Bhowmick S, Zhang Y, Lawn BR. Competing fracture modes in brittle materials subject to concentrated cyclic loading in liquid environments: Trilayer structures. J Mater Res 2006; 21: 512-21.

[92] Mora GP, O'Brien WJ. Thermal shock resistance of core reinforced all-ceramic crown systems. J Biomed Mater Res 1994; 28: 189-94.

[93] Komine F, Saito A, Kobayashi K, Koizuka M, Koizumi H, Matsumura $\mathrm{H}$. Effect of cooling rate on shear bond strength of veneering porcelain to a zirconia ceramic material. J Oral Sci 2010; 52: 64752 .

[94] Gostemeyer G, Jendras M, Dittmer MP, Bach FW, Stiesch M, Kohorst P. Influence of cooling rate on zirconia/veneer interfacial adhesion. Acta Biomater 2010; 6: 4532-8.

[95] Swain MV. Unstable cracking (chipping) of veneering porcelain on all-ceramic dental crowns and fixed partial dentures. Acta Biomater 2009; 5: 1668-77.

[96] Taskonak B, Borges GA, Mecholsky JJ Jr., Anusavice KJ, Moore BK, Yan J. The effects of viscoelastic parameters on residual stress development in a zirconia/glass bilayer dental ceramic. Dent Mater 2008; 24: 1149-55.

[97] Rues S, Kroger E, Muller D, Schmitter M. Effect of firing protocols on cohesive failure of all-ceramic crowns. J Dent 2010; 38 987-94.

[98] Fischer J, Stawarczyck B, Sailer I, Ha"mmerle CH. Shear bond strength between veneering ceramics and ceria-stabilized zirconia/alumina. J Prosthetic Dent 2010; 103: 267-74.

[99] Hong JK, Hyum PL, Park YJ, Vang MS. Effect of zirconia surface treatments on the shear bond strength of veneering ceramic. J Prosthetic Dent 2011; 105: 315-22.

[100] Beuer F, Schweiger J, Eichberger M, Kappert HF, Gernet W, Edelhoff D. High-strength CAD/CAM-fabricated veneering material sintered to zirconia copings - a new fabrication mode for allceramic restorations. Dent Mater 2009; 25: 121-8. 
[101] Beuer F, Edelhoff D, Gernet W, Sorensen JA. Three-year clinical prospective evaluation of zirconia-based posterior Foxed Dental Prostheses (FDPs). Clin Oral Investigat 2009; 13: 445-51.

[102] Coffey JP, Anusavice KJ, DeHoff PH, Lee RB, Hojjatie B. Influence of contraction mismatch and cooling rate on flexural failure of PFM systems. J Dent Res 1988; 67: 61-5.

[103] Isgro' G, Addison O, Fleming GJP. Transient and residual stresses induced during the sintering of two dentine ceramics. Dent Mater 2010; 27: 379-85.

[104] McLean JW, Hughes TH. The reinforcement of dental porcelain with ceramic oxides. Br Dent J 1965; 119: 251-67.

[105] Isgro G, Addison O, Fleming GJP. Transient and residual stresses in a pressable glass-ceramic before and after resin-cement coating determined using profilometry. J Dent 2011; 39: 368-75.

[106] Tholey MJ, Swain MV, Thiel N. SEM observations of porcelain Y-TZP interface. Dent Mater 2009; 25: 857-62.

[107] Albashaireh ZSM, Ghazal M, Kern M. Two-body wear of different ceramic materials opposed to zirconia ceramic. J Prosthetic Dent 2010; 104: 105-13.

[108] Stawarczyk B, Özcan M, Roos M, Trottmann I, Sailer I, Hämmerle CHF. Load-bearing capacity and failure types of anterior zirconiacrowns veneered with overpressing and layering techniques. Dent Mater 2011; 27: 1045-53.

[109] Drummond JL. Ceramic behavior under different environmental and loading conditions. Dental materials in vivo: aging and related phenomena. 2003, Quinte Chicago, IL. p. 35-45.

[110] Holden JE, Goldstein GR, Hittelman EL, Clark EA. Comparison of the marginal fit of pressable ceramic to metal ceramic restorations. J Prosthodont 2009; 18: 645-8.

[111] Kim MJ, Kim YK, Kim KH, Kwon TY. Shear bond strengths of various luting cements to zirconia ceramic: surface chemical aspects. J Dent 2011; 39: 795-803.

[112] Albrecht T, Kirsten A, Kapperta HF, Fischerb H. Fracture load of different crown systems on zirconia implant abutments. Dent Mater 2011; 27: 298-303.

[113] Guess C, Zavanelli R, Silva N, Bonfante E, Coelho P, Thompson V. Monolithic CAD/CAM Lithium Disilicate versus Veneered YTZP crowns: comparison of failure modes and reliability after fatigue. Int J Prosthodont 2010; 23: 343-442.

[114] Christensen RP, Eriksson KA, Ploeger BJ. Clinical performance of PFM, zirconia and alumina three-unit posterior protheses. IADR Toronto 2008 [Abstract no. 105962].

[115] Ishibe M, Raigrodski A, Flinn BD, Chung KH, Spiekerman C, Winter RR. Shear bond strengths of pressed and layered veneering ceramics to high-noble alloy and zirconia cores. J Prosthetic Dent 2011; 106: 29-37.

[116] Scherrer SS, Cesar PF, Swain MV. Direct comparison of the bond strength results of the different test methods: a critical literature review. Dent Mater 2010; 26: e78-93.

[117] Guess PC, Zhang Y, Thompson VP. Effect of veneering techniques on damage and reliability of Y-TZP trilayers. Eur J Esthet Dent 2009; 4: 262-76.

[118] Plengsombut K, Brewer JD, Monaco EA Jr., Davis EL. Effect of two connector designs on the fracture resistance of all-ceramic core materials for fixed dental prostheses. J Prosthetic Dent 2009; 101:166-73.

[119] International Organization for Standardization. I., metal-ceramic dental restorative systems. Organization for Standardization; Geneva: Int., 1999

[120] Al-Dohan HM, Yaman P, Dennison JB, Razzoog ME, Lang BR. Shear strength of core-veneer interface in bi-layered ceramics. J Prosthetic Dent 2004; 91: 349-55.

[121] Suese K. Comparison of bond strength of porcelain fused to core materials of metal and zirconia. J Osaka Dent Univ 2010; 44: 41-7.

[122] Ashkanani HM, Raigrodski A, Flinn BD, Heindl H, Mancl LA. Flexural and shear strengths of $\mathrm{ZrO}_{2}$ and a high-noble alloy bonded to their corresponding porcelains. J Prosthetic Dent 2008; 100: 27484.

[123] Silva NRFA, Bonfante EA, Zavanelli RA, Thompson VP, Ferencz JL, Coelho GP. Reliability of metalloceramic and Zirconia-based ceramic crowns. J Dent Res 2010; 89(10): 1051-6.

[124] Mackert Jr Jr., Ringle R, Parry EE, Evans AL, Fairhurst CW. The relationship between oxide adherence and porcelain-metal bonding. J Dent Res 1988; 67: 474-8.

[125] Schweitzer DM, Goldstein G, Ricci JL, Silva NR, Hittelman EL. Comparison of bond strength of a pressed ceramic fused to metal versus feldspathic porcelain fused to metal. J Prosthodont 2005; 14 : 239-47.

[126] Ernsberger FM. The role of molecular water in the diffusive transport of protons in glasses. Physics Chem Glasses 1980; 21: 146-9.

[127] Newton RG. The durability of glass-a review. Glass Technol 1985; 26: 21-38.

[128] Peterson IM, Wuttiphan S, Lawn BR, Chyung K. Role of microstructure on contact damage and strength degradation of micaceous glass-ceramics. Dent Mater 1998; 14: 80-9.

[129] Zhang Y, Song J, Lawn BR. Deep-penetrating conical cracks in brittle layers from hydraulic cyclic contact. J Biomed Mater Res B Appl Biomater 2005; 73: 186-93.

[130] Att W, Stamouli K, Gerds T, Strub JR. Fracture resistance of different zirconium dioxide three-unit all-ceramic fixed partial dentures. Acta Odontol Scand 2007; 65: 14-21.

[131] Beuer F, Bastian S, Naumann M, Sorensen JA. Load-bearing capacity of all-ceramic three-unit fixed partial dentures with different computer-aided design (CAD)/computer-aided manufacturing (CAM) fabricated framework materials. Eur J Oral Sci 2008; 116 : 381-6.

[132] Petridis H, Hirayama H, Kugel G, Habib C, Garefis P. Shear bond strength of techniques for bonding esthetic veneers to metal. J Prosthetic Dent 1999; 82: 608-14.

[133] Tsalouchou E, Cattell MJ, Knowles JC, Pittayachawan P, McDonald A. Fatigue and fracture properties of yttria partially stabilized zirconia crown systems. Dent Mater 2008; 24: 308-18.

[134] Fischer J, Stawarzcyk B, Hämmerle CH. Flexural strength of veneering ceramics for zirconia. J Dent 2008; 36(5): 316-21.

[135] Raptis NV, Michalakis K, Hirayama H. Optical behavior of current ceramic systems. Int J Periodont Restor Dent 2006; 26: 31-41.

[136] Ardlin BI. Transformation-toughened zirconia for dental inlays, crowns and bridges: chemical stability and effect of lowtemperature aging on flexural strength and surface structure. Dent Mater 2002; 18: 590-5.

[137] Heffernan MJ, Aquilino S, Diaz-Arnold AM, et al. Relative translucency of six all-ceramic systems. Part II: core and veneer materials. J Prosthetic Dent 2002; 88: 10-5.

[138] Devigus A, Lombardi G. Shading Vita In-ceram YZ substructures: influence on value and chroma, part II. Int J Comput Dent 2004; 7 : 379-88.

[139] Raigrodski AJ. Contemporary all-ceramic fixed partial dentures: a review. Dent Clin North Am 2004. 48: 531-44.

[140] Aboushelib MN, Kleverlaan C, Feilzer AJ. Microtensile bond strength of different components of core veneered all-ceramic restorations. part 3: double veneer technique. J Prosthodont 2008; 17: 9-13.

[141] Chen PL, Chen IW. Grain boundary mobility in $\mathrm{Y}_{2} \mathrm{O}_{3}$ : defect mechanism and dopant effects. J Am Ceram Soc 1996; 79: 1801-9.

[142] Deville S, Gremillard L, Chevalier J, Fantozzi G. A critical comparison of methods for the determination of the aging sensitivity in biomedical grade yttria-stabilized zirconia. J Biomed Mater Res B Appl Biomater 2005; 72: 239-45.

[143] Pittayachawan P, McDonald A, Petrie A, Knowles J. The biaxial flexural strength and fatigue property of Lava(TM) Y-TZP dental ceramic. Dent Mater 2007; 23: 1018-29.

[144] Carlsson GE. Critical review of some dogmas in prosthodontics. J Prosthodont Res 2009; 53: 3-10.

[145] DeLong R, Douglas W. Development of an artificial oral environment for the testing of dental restoratives: bi-axial force and movement control. J Dent Res 1983; 62: 32-6.

[146] Nico H, Creugers J, Arnd F, Kayser and Martin A, van 't Hof. A meta-analysis of durability data on conventional fixed bridges. Commun Dent Oral Epidemiol 1994; 22: 448-52.

[147] Yeo IS, Yang JH, Lee JB. In vitro marginal fit of three all-ceramic crown systems. J Prosthetic Dent 2003; 90: 459-64.

[148] De Jager N, Pallav P, Feilzer AJ. The influence of design parameters on FEA-determined stress distribution in CAD-CAM produced all-ceramic crowns. Dent Mater 2005; 21: 242-51.

[149] Burke FJ, Fleming GJ, Nathanson D, Marquis PM. Are adhesive technologies needed to support ceramics? an assessment of the current evidence. J Adhes Dent 2002; 4: 7-22.

[150] Marquardt P, Strub JR. Survival rates of IPS Empress 2 all-ceramic crowns and fixed partial dentures: results of a 5-year prospective clinical study. Quint Int 2006; 37: 253-9.

[151] Piconi C, Maccauro G. Zirconia as a ceramic material. Biomaterials 1999; 20: 1-25. 
[152] Yanagida H, Koumoto K, Miyayama M. The chemistry of ceramics. 1996, Chichester, UK: John Wiley \& Sons, Ltd. 247-9.

[153] Guazzato M, Quach L, Albakry M, Swain MV. Influence of surface and heat treatments on the flexural strength of Y-TZP dental ceramic. J Dent 2005; 33: 9-18.

[154] Sailer I, Feher A, Filser F, Gauckler LJ, Luthy H, Hammerle CH. Five-year clinical results of zirconia frameworks for posterior fixed partial dentures. Int J Prosthodont 2007; 20: 383-8.

[155] Chong KH, Chai J, Takahashi Y, Wozniak W. Flexural strength of In-Ceram alumina and In-Ceram zirconia core materials. Int $\mathbf{J}$ Prosthodont 2002; 15: 183-8.

[156] Bindl A, Mormann WH. Marginal and internal fit of all-ceramic CAD/CAM crown copings on chamfer preparations. J Oral Rehab 2005; 32: 441-7.

[157] Sadowsky SJ. An overview of treatment considerations for esthetic restorations: a review of the literature. J Prosthetic Dent 2006; 96: 433-42.

[158] Studart AR, Filser F, Kocher P, Luthy H, Gauckler LJ. Mechanical and fracture behavior of veneer-framework composites for allceramic dental bridges. Dent Mater 2007; 23: 115-23.

[159] Aboushelib MN, Feilzer A, de Jager N, Kleverlaan CJ. Prestresses in bilayered allceramic restorations. J Biomed Mater Res B Appl Biomater 2008; 87: 139-45.

[160] de Kler M, deJager N, Meegdes M, van der Zel JM. Influence of thermal expansion mismatch and fatigue loading on phase changes in porcelain veneered Y-TZP zirconia discs. J Oral Rehabil 2007; 34: 841-7.

[161] Wang H, Aboushelib MN, Feilzer AJ. Strength influencing variables on CAD/CAM zirconia frameworks. Dent Mater 2008; 24: 633-8.

[162] Oilo G, Johanson B, Syverud M. Bond strength of porcelain to dental alloys-an evaluation of two test methods. Scand J Dent Res 1981; 89: 289-96.

[163] Ban S, Sato H, Suehiro Y, Nakanishi H, Nawa M. Biaxial flexure strength and low temperature degradation of $\mathrm{Ce}-\mathrm{TZP} / \mathrm{Al}_{2} \mathrm{O}_{3}$ nanocomposite and Y-TZP as dental restoratives. J Biomed Mater Res B Appl Biomater 2008; 87: 492-8.

[164] Kim B, Zhang Y, Pines M, Thompson VP. Fracture of porcelainveneered structures in fatigue. J Dent Res 2007; 86: 142-6.

[165] Donovan TE. Factors essential for successful all-ceramic restorations. J Am Dent Assoc 2008; 139(Suppl): 14S-8S.

[166] Hermann I, Bhowmick S, Lawn BR. Role of core support material in veneer failure of brittle layer structures. J Biomed Mater Res B Appl Biomater 2007; 82: 115-21.
[167] Aboushelib MN, deJager N, Kleverlaan CJ, Feilzer AJ. Microtensile bond strength of different components of core veneered allceramic restorations. Dent Mater 2005; 21: 984-91.

[168] Wassermann A, Kaiser M, Strub JR. Clinical long-term results of VITA Inceram classic crowns and fixed partial dentures: a systematic review. Int J Prosthodont 2006; 19: 355-63.

[169] Heffernan MJ, Aquilino SA, Diaz-Arnold AM, Haselton DR, Stanford CM, Vargas MA. Relative translucency of six all-ceramic systems. part I: core materials J Prosthetic Dent 2002; 88: 4-9.

[170] Heffernan MJ, Aquilino S, Diaz-Arnold AM, Haselton DR, Stanford CM, Vargas M. Relative translucency of six all-ceramic systems. Part II: core and veneer materials. J Prosthetic Dent 2002; 88: $10-5$.

[171] Suarez MJ, Lozano J, Paz Salido M, Martinez F. Three-year clinical evaluation of In-Ceram Zirconia posterior FPDs. Int J Prosthodont 2004; 17: 35-8.

[172] Raigrodski AJ, Chiche G. The safety and efficacy of anterior ceramic fixed partial dentures: a review of the literature. J Prosthetic Dent 2001; 86: 520-5.

[173] Luthy H, Filser F, Loeffel O, Schumacher M, Gaucker LJ, Hammerle CHF. Strength and reliability of four-unit all-ceramic posterior bridges. Dent Mater 2005; 21: 930-7.

[174] Raigrodski AJ. Contemporary materials and technologies for allceramic fixed partial dentures: a review of literature. J Prosthetic Dent 2004; 92: 557-62.

[175] Scarano A, Di Carlo F, Quaranta M, Piattelli A. Bone response to zirconia ceramic implants: an experimental study in rabbits. J Oral Implantol 2003; 29: 8-12.

[176] Raigrodski AJ. Contemporary all-ceramic fixed partial dentures: a review. Dent Clin North Am 200; 48: 531-44.

[177] Tinschert J, Natt G, Mautsch W, Augthun M, Spikermann H. Fracture resistance of lithium disilicate-, alumina-, and zirconia-based three-unit fixed partial dentures: a laboratory study. Int J Prosthodont 2001; 14: 231-8.

[178] Guazzato M, Proos K, Quach L, Swain MV. Strength reliability and mode of fracture of bilayered porcelain/zirconia (Y-TZP) dental ceramics. Biomaterials 2004; 25: 5045-52.

[179] Kosmac T, Oblak C, Jevnikar P, Funduk N, Marion L. Strength and reliability of surface treated Y-TZP dental ceramics. J Biomed Mater Res 2000; 53: 304-13.

[180] Reich S, Wichmann M, Nkenke E, Proeschel P. Clinical fit of allceramic three-unit fixed partial dentures, generated with three different CAD/CAM systems. Eur J Oral Sci 2005; 113: 174-9.

[181] Ernest Claus-Peter, Cohnen U, Stender Elmar, Willershausen Brita. In vitro retentive strength of zirconium oxide ceramic crowns using different luting agents. J Prosthetic Dent 2005; 93: 551-8. (http://creativecommons.org/licenses/by-nc/3.0/) which permits unrestricted, non-commercial use, distribution and reproduction in any medium, provided the work is properly cited. 